\title{
Ev Ödevleri: Öğretmen, Öğrenci ve Veli Görüşleri ${ }^{1}$
}

DOI: 10.26466/opus.544599

*

\author{
Mustafa Ok* - Muhittin Calıskan**
}

*Öğretmen, PEMA Koleji, Selçuklu / Konya / Türkiye

E-Posta: mustafa.ok.pema@gmail.com ORCID: 0000-0002-8319-9523

** Doç. Dr., Necmettin Erbakan Üni. Ahmet Keleşoğlu Eğitim Fak., Meram/Konya/Türkiye

E-Posta: $\underline{\text { mcaliskan@erbakan.edu.tr }}$

ORCID: 0000-0002-2341-0710

\section{Öz}

Bu araştırmada, son dönemlerin tartışmalı konularından biri olan ödevler üzerine çalışılmıştır. Öğretmenlerin, öğrencilerin ve velilerinin ev ödevine yönelik görüşlerinin incelenmesini amaçlayan bu çalışmanın çalışma grubunu, 2016 - 2017 eğitim öğretim yılında Konya il merkezindeki iki farklı ilkokuldan toplamda 37 öğretmen, 335 öğrenci ve 222 veli oluşturmaktadır. Nitel araştırma yönteminde gerçekleştirilen bu araştırmanın verileri öğretmenlerden ve velilerden yarı yapılandırılmış görüşme formu ile toplanmıştır. Öğrenci verileri ise öğrencilerin ev ödevi ile ilgili çizdikleri resimlerden elde edilmiştir. Veriler içerik analizi ile çözümlenmiştir. Araştırma sonunda ulaşılan sonuçlar şunlardır: 1. Öğretmenler ev ödevine pekiştirme, tekrar, görev ve sorumluluk gibi anlamlar atfetmektedirler. 2. Veliler de benzer şekilde ev ödevini genel olarak tekrar, pekiştirme ve görev olarak ele almaktadırlar. 3. Öğrencilerin sınıf ortamı gibi kapalı mekanları sıkça resmettikleri tespit edilmiştir. 4. Velilerin ve öğretmenlerin ödev konusunda bazı noktalarda görüşleri birbirinden farklllaşmaktadır.

Anahtar Kelimeler: Ev ödevi, Ödev türleri, İdeal ödev

\footnotetext{
${ }^{1}$ Bu çalışma birinci yazarın hazırladığı yüksek lisans tezinden üretilmiştir.
} 


\title{
Homework: Opinions of Teachers, Students and Parents
}

\begin{abstract}
In this research, one of the controversial issues of recent years, homeworks has been studied. The study group of this study, aiming to examine the meanings that teachers, students and parents meaning attribution to homeworks constitutes 37 teachers, 335 students and 222 parents from two different primary schools in Konya province in 2016 - 2017 academic year. The data of this research carried out in the qualitative research method were collected by the semi-structured interview form formed by the researcher from the teachers and parents. Student data is obtained from the pictures drawn by students about homework. The obtained data were analyzed by content analysis. The results obtained at the end of the research are as follows:1. It has been determined that teachers attributed meanings such as reinforcement, repetition, duty and responsibility for homework;: 2. It has also been found that student parents generally treat homework as a repetition, consolidation and task; 3. It has been found out that students frequently display indoor places such as the classroom environment related to homework; 4 . It has been determined that the opinions of the parents and teachers differ from each other in terms of homework.
\end{abstract}

Keywords : Homework, Types of homework, Ideal homework 


\section{Giriş}

Ödevler, günümüz öğrenme ortamlarında sıkça yer alan bir kavram olarak karşımıza çıkmaktadır. Öğrenmeye yardımcı olma, öğrenme eksiklerini tamamlama, derse hazırlama gibi beklentiler atfedilen ödevler; okul, ev, dershane veya etüt merkezi gibi farklı ortamlarda; proje ödevi, dönemlik ödev, test çözme ödevi, yazı yazma ödevi, maket yapma, deney yapma ödevi gibi farklı şekillerde ve farklı miktarlarda yer almaktadır. Fakat her zaman doğru yerde, doğru şekilde ve yeterli miktarda öğrenmeye katkı sağladığı düşünülmemektedir (Yeşilyurt, 2006; Yolcu, 2007).

Bazen bir not verme aracı, bazen de ceza unsuru olarak öğrenciye verilen ödevler, aslında öğrenciyi derse motive etmeli, açıkları kapatmalı, eksik ve yarım kalan öğrenmeleri tamamlamalıdır. Ayrıca, öğrencilerin davranışlarında kalıcı izli değişiklikler oluşturabilmek için sınıf ortamında kazandırılan davranış ve kazanımların sınıf dışında da pekiştirilmesi ve yeni kazanımlarla desteklenmesi gerekmektedir (Şen ve Gülcan, 2012). Ancak, öğrenciye pek çok yönden katkı sağlaması beklenen ödevlerin; bekleneni her zaman yerine getirmekte mi, yoksa çoğu zaman bir karmaşaya mı dönüşmekte olduğu tartışma konusudur.

Öğrenme üzerinde önemli bir etkiye sahip olduğu düşünülen ödeve dair yapılan tanımlar incelendiğinde ödevin; öğretmenlerin herhangi bir konuyu pekiştirmek, eksik öğrenmeleri gidermek ya da yeni bir konuya hazırlık yapmak amacıyla öğrencilere verdikleri her türden okul ve ders dışı etkinlikler ve görevlendirmeler olduğu anlaşılmaktadır. Ödevi sadece tanımlamak, onu amacina uygun olarak kullanabilmek ve ödev sayesinde verimli sonuçlar elde edebilmek için yeterli değildir. Ödevin ne olduğunun ve neden gerekli olduğunun yanında ödevin amaçları, türleri, olumlu ve olumsuz etkileri, ideal bir ödev sürecinin nasıl yönetilmesi gerektiği de bilinmelidir (Büyüktokatlı, 2009; Kütükte, 2010; Oğuz, 2010).

Ödevi öğrenmede kullanmanın amacı, öğrenciye sorumluluk bilincini kazandırabilmek, etkili iletişim becerileri kazandırmak, öğrencinin ders ile geçirdiği zamanı artırmak, derse hazırlıklı gelmesini sağlamak ve öğrenmesini pekiştirme yoluyla kalıcı hale getirmektir. Ayrıca ödev yaparken kazanılması gereken en temel sosyal beceriler; duygu ve düşünceleri ifade edebilme, başkalarına güven ve olabilecek riskleri karşılayabilme, yeni arkadaşlıklara açı olma, söylemek istediğini karşı tarafa 
doğru anlaşılabilecek şekilde aktarabilme, sürekli sosyal ilişkiler oluşturabilme, değişik düşüncelere sahip olabilmeyi normal karşılama ve kabul etmedir (Gür, 2002; Hizmetçi, 2007).

Tüm bu amaçları sağlamaya yönelik düzenlenen ödevler Türkoğlu, İflazoğlu ve Karakuş'a (2014) göre pratik ödevleri, hazırlık ödevleri ve geliştirme ödevleri olarak üç grupta toplanabilir. Ancak ödev türleri konusunda yalnızca bu üç türle sınırlı kalınmamalıdır. Gerçekleştirdikleri hedeflere göre de ödevler; öğrenmeyi pekiştiren ödevler, öğrenmeyi tamamlayan / bütünleştiren ödevler, öğrenmeye hazırlayan ödevler, öğrenmeyi sistematikleştiren ödevler veya öğrenmeyi genişleten ödevler olarak da sinıflandırılabilir.

Hangi sınıflandırmaya dâhil olursa olsun verilen her ödevin öğrenci ve öğrenme üzerinde birtakım olumlu ya da olumsuz etkileri ortaya çıkmaktadır. Bu etkiler çoğu kez Büyüktokatlı'nın (2009) belirttiği gibi ödevlerin öğrenciyi akademik olarak daha başarılı kılması, öğrenmeyi ve okuldaki başarıyı pekiştirmesi, öğrenciyi yeni alanlarla tanıştırması, kurallara uymayı, işe zamanında başlamayı ve bitirmeyi, sorumluluk üstlenmeyi, kendi başına iş yapma yeteneğini öğretmesi gibi olumlu etkiler olarak gözlenmektedir. Ancak tüm bu olumlu etkilerin yanında, ödevin verilme amacı olması gerekenin dışına çıktığında ya da yapılma şekli değiştirildiğinde veya doğru şekilde değerlendirilmediğinde, ödevler amacına ulaşamamaktadır.

Yolcu'ya (2007) göre, öğrenciler, ödevlerle ilgili sürekli olarak şikâyetlerini dile getirmektedirler. Ayrıca aileler de ödevlerin kendilerine ek bir yük getirdiğinden bahsetmektedirler. Ödevler aynı zamanda eğitimcilerin de ödevlerini yapmayı reddeden öğrencilerle uğraşmak zorunda olmaları gibi ekstra çalışma yapmalarına neden olmaktadır. Bu yüzden ödevin bir eğitim aracı olarak faydaları konusunda soru işaretleri yer almaktadır (Gür, 2003; Gürlevik, 2006; Öcal, 2009).

Ödeve dair olumsuz düşünceler, ön yargılar ve ödevin ortaya çıkardığı olumsuz etkiler ödev sürecinin iyi yönetilememesinin bir sonucudur. Öğretmenin ödev vermeye karar vermesi ile başlayıp, ödeve ilişkin geri dönüt alan öğrencinin düzeltmeler yapması ile sona eren bir süreç olan ödevler, iyi yönetilemediğinde problemlere yol açmaktadır (Kapıkıran ve Kıran, 1999; Özer ve Öcal, 2013; Turanl1, 2009b). Doğru zamanda, doğru 
miktarda ve doğru şekilde verilen ödevler, dönüt ve düzeltmenin yapılmasıyla birlikte olumsuz sonuçları ortaya çıkarmayacaktır. Olumsuz sonuçların ortaya çıkmasında en büyük etkenlerden biri de Turanlı'nın (2007) belirttiği gibi öğretmen, veli ve öğrencilerin okula ilişkin farklı bakış açılarına sahip olmalarıdır. Bu paydaşların okulun görevlerini tanımlayışlarındaki farklılaşma, ödeve ve ödev yapmaya farklı anlamlar yüklemelerini de kaçınılmaz kılar. Okulun görevlerini, işleyişini ve etkilerini farklı yorumlayan bireyler okulda devam eden eğitim - öğretim süreçlerini de bu farklılıklar doğrultusunda yorumlayacaktır. Eğitim öğretimin ayrılmaz parçası olan ödevlere ve ödev yapmaya karşı geliştirilen yargılar ve bakış açıları da bu ölçüde farklı olacaktır. Ayrıca paydaşlar arasındaki bu farklılıklar paydaşların, birbirlerinin bakış açısından yeterince haberdar olmadığına işaret etmektedir (Turanll, 2009b).

Öğretmenler, öğrenciler ve veliler arasında ev ödevlerine ilişkin gözlenen farklı görüşler, tutumlar ve beklentiler güncel bir araştırma konusu olarak karşımıza çıkmaktadır. Bu konu üzerine yapılan araştırmaların bir kısmının öğretmen görüşlerine odaklandığı, bir kısmının öğrenci görüşlerine odaklandığı, bir kısmının ise veli görüşlerine odaklandığı görülmektedir. Örneğin; Gedik, Altıntaş ve Kaya (2011) ödevler hakkında öğrenci görüşlerini araştırmışlardır. Benzer şekilde Gedik ve Orhan (2013) araştırmalarında öğrenci görüşleri üzerine odaklanmışlardır. Şen ve Gülcan (2012) yaptıkları araştırmada ev ödevleri hakkında veli görüşlerini belirlemeyi amaçlamışlardır. Özer ve Öcal (2013) ise ev ödevleri hakkında öğretmenlerin görüşlerini araştırmıştır. Benzer şekilde Turanlı da (2009b) ödeve ilişkin yaptığı araştırmada öğretmen görüşlerini belirlemeyi hedeflemiştir. Öcal da (2009) ev ödevleri konusunda ailelerin ve öğretmenlerin rolünü araştırmıştır. Ayrıca Gürlevik (2006) gibi öğretmen ve öğrenci görüşlerine birlikte odaklanan ve Deveci (2011) gibi öğretmen, öğrenci ve veli görüşlerinin bir arada incelendiği çalışmalar da bulunmaktadır.

Turanlı'nın (2007) yaptığı araştırmada öğretmenlerin, öğrencilerin ve velilerin ödev algılarının birbirinden farklı olduğu görülmektedir. Öğretmenler, ödevle ilgili sorumlulukların bilmekte fakat aile ile yeterince iletişime geçmemekte, bu nedenle söz konusu görüş farklılıkları ortadan kalkmamaktadır. Aileler de öğretmenlerin yeterince iletişim halinde olmamasından şikayet etmekle birlikte çoğu kez öğrenciye ödev konusunda 
nasıl yardımcı olacaklarını bilmemektedir. Öğrenciler ise bu görüş farklılıklarının arasında kendilerine en kolay gelen şekilde ödevlerinin büyük bir kısmını anne ve babalarına yaptırmaktadırlar. Bu karmaşa içinde, konunun muhatabı olan öğretmen, öğrenci ve anne-babaların konuya yaklaşımını belirlemek, birbirlerini anlamalarını ve birbirlerine anlayışla yaklaşmalarını sağlayarak, uygulamadan verim alınmasını sağlamak gerekmektedir (Turanl, 2007).

Öğretmenlerin, öğrencilerin ve velilerin ev ödevlerine ilişkin görüşlerinin incelenmesi ve benzer görüşlerin ortaya çıarılması önemli görülmektedir. Benzer görüşler dikkate alınarak ödev verildiğinde ve süreç yönetildiğinde ödev konusunda yaşanan sorunların en aza indirilebileceği düşünülmektedir. Bu nedenle bu araştırmanın genel amacı, ilkokul kademesinde, ev ödevlerine ilişkin öğretmen, öğrenci ve veli görüşlerini incelemektir. Bu amaçla aşağıdaki sorulara cevap aranmıştır:

1. Öğretmenlerin ev ödevlerine ilişkin görüşleri nelerdir?

2. Öğrencilerin ev ödevlerine ilişkin görüşleri nelerdir?

3. Velilerin ev ödevlerine ilişkin görüşleri nelerdir?

4. Öğretmenlerin ve velilerin ev ödevlerine ilişkin görüşleri arasında benzer ve farklı yönler nelerdir?

\section{Yöntem}

\section{Çalışma Grubu}

Tablo 1. Öğrencilerin Okul Türü, Sınıf ve Cinsiyete Göre Dağılımı

\begin{tabular}{lcccc}
\hline Okul Türü & Sinıf Düzeyi & Erkek & Kiz & Toplam \\
\hline Devlet Okulu & 1. Sinif & 31 & 24 & 55 \\
& 2. Sinıf & 23 & 31 & 54 \\
& 3. Sinıf & 17 & 24 & 41 \\
& 4. Sinif & 27 & 16 & 43 \\
\hline Özel Okul & 1. Sinif & 25 & 7 & 32 \\
& 2. Sinif & 27 & 21 & 48 \\
& 3. Sinif & 9 & 11 & 20 \\
& 4. Sinif & 15 & 27 & 42 \\
\hline & Toplam & $\mathbf{1 7 4}$ & $\mathbf{1 6 1}$ & $\mathbf{3 3 5}$ \\
\hline
\end{tabular}


Nitel araştırma yöntemiyle durum çalışması olarak desenlenen bu araştırmanın çalışma grubu, kolay ulaşılabilir durum örnekleme tekniğinden yararlanılarak oluşturulmuştur. Bir özel okul ve bir devlet okulu olmak üzere iki ilkokulda 37 öğretmen, 335 öğrenci ve 222 veli ile çalışılmıştır. Öğrencilerin okul türü, sınıf ve cinsiyete göre dağılımı Tablo 1 'de gösterilmiştir.

\section{Veri Toplama Araçlan}

$\mathrm{Bu}$ araştırmada veriler, öğretmenler ve veliler için ayrı ayrı olmak üzere iki yarı yapılandırılmış görüşme formu ve öğrencilere yaptırılan resimler ile toplanmıştır. Her iki görüşme formunda da 9 adet soru vardır. Sorular araştırmacı tarafından taslak olarak hazırlanmış, konu ile ilgili daha önce yapılan araştırmalardan elde edilen bilgiler ışığında taslak sorular bir araya getirilerek soru havuzu oluşturulmuş, daha sonra sorular uzman görüşleri doğrultusunda elenerek ölçme aracı son şekli verilmiştir. Öğrencilere ise "Ödev denince aklınıza ne geliyor? Resmini çiziniz." yönlendirmesi yapılmış ve yapılan resimler araştırmacı tarafından öğrencilerden alınmıştır. Öğrenciler resim yaparken süre, kâğıt boyutu, renk, kalem türü gibi herhangi bir sinırlama uygulanmamıştır.

\section{Verilerin Toplanması}

Bu araştırmanın çalışma grubunda yer alan öğretmenlere ve velilere öncelikle bu araştırmaya katılıp katılmak istemedikleri sorulmuş, araştırmaya katılmak istediklerini belirten öğretmen ve velilere araştırma ile ilgili kapsamlı bilgi verildikten sonra veri toplama araçları kendilerine teslim edilmiş; belirlenen bir haftalık sürenin sonunda katılımcıların yanıtladıkları görüşme formları yine kendilerinden teslim alınmıştır.

Öğrencilerden toplanan veriler ise, araştırmaya katılmak istediklerini belirten öğretmenlerin sınıflarında bir ders saati süresince öğrencilere önce bilgilendirme ve sonrasında yönerge vererek resim yaptırma yoluyla toplanmıştır. İlkokul düzeyindeki öğrencilerden resimlerle daha iyi veri toplanabileceği düşünülmüştür. 


\section{Verilerin Analizi}

Bu araştırmada görüşme formlarından elde edilen verilerin analizinde içerik analizi ve öğrenci resimlerinden elde edilen verilerin analizinde görsel analiz tekniği işe koşulmuştur. Doküman analizinin bir alt başlığı olarak ele alınabilen görsel analizde görsel verilerin analizi yapılmaktadır. Görsel analiz, görsel verilerin, simgelerin, sembollerin, işaretlerin açıklanıp yorumlanması şeklinde tanımlanabilmektedir (Sönmez ve Alacapınar, 2014).

\section{Geçerlik ve Güvenirlik}

Nitel araştırmalarda içerik analizlerinin güvenirliği kodlamanın ne derecede doğru yapıldığı ile doğru orantılıdır (Bilgin, 2014). Bu nedenle öğretmenlerin ve velilerin yarı yapılandırılmış görüşme formlarında yer alan açık uçlu sorulara verdikleri cevaplar önce araştırmacı tarafından, sonra da tez danışmanı tarafından ayrı ayrı kodlanmıştır. Ayrıca öğrenci resimlerinden elde edilen veriler de doğrultusunda tez danışmanı tarafından tekrar kodlanmıştır. Elde edilen tema ve alt temalar için "görüş birliği" ve "görüş ayrılığı" olan konular tartışılmış ve gerekli düzenlemeler yapılmıştır. Güvenirlik hesaplaması için Miles ve Huberman'ın (1994'den akt. Tavşancıl, 2001, s.81) önerdiği güvenirlik formülü kullanılmıştır. [Güvenirlik = Görüş Birliği / (Görüş Birliği + Görüş Ayrılığı)]. Hesaplama sonucunda güvenirlik; öğretmen görüşme formları için \%87.068, öğrenci resimleri için \%83.732, veli görüşme formları için \%89.224 olarak hesaplanmıştır. Güvenirlik hesaplarının \%70'in üzerinde çıkması, araştırma kapsamında elde edilen veriler için güvenilir kabul edilmektedir (Miles ve $\mathrm{Hu}$ berman, 1994'den akt. Tavşancil, 2001, s. 81). 


\section{Bulgular}

\section{Araştırmanın Birinci Sorusuna İlişkin Bulgular}

Bu başlıkta öğretmenlerin ödevlere yükledikleri anlamların incelenmesi amacıyla veri toplama aracında öğretmenlere yöneltilen sorulara öğretmenlerin

verdikleri yanıtların analizi sonucunda ulaşılan bulgulara yer verilmiştir.

Tablo 2. Öğretmenlere Yöneltilen "Ödev denildiğinde ne anlıyorsunuz? Ödev sizin için nasıl bir anlam ifade ediyor?" Sorusuna Verdikleri Cevaplarn Frekans Tablosu

\begin{tabular}{lc}
\hline Kodlar & $\mathbf{f}$ \\
\hline Pekiştirme ve tekrar & 28 \\
Görev ve sorumluluk & 19 \\
Her türden çalışma ve etkinlik & 17 \\
Zorlama ve eziyet yöntemi & 15 \\
Araştırma & 12 \\
Derse ön hazırlık & 10 \\
Düzenli ders çalışma alışkanlı̆̆ı kazandırma & 9 \\
Dersin verimliliğini artırma çalışması & 8 \\
Teknolojiden uzaklaştırma yolu & 7 \\
Gelişme aracı & 6 \\
Zamanı değerlendirme aracı & 5 \\
Bilgiyi keşfetme yolu & 5 \\
Bilgi edinme aracı & 3 \\
Güdüleme yöntemi & 3 \\
Okulu sevdirme aracı & 3 \\
Ahlaki değer kazandırma yöntemi & 3 \\
Hareketliliği azaltma yöntemi & 2 \\
Hedefe ulaşma yolu & 1 \\
Ö̆ğrenciyi olumlu yöne sevk etme aracı & 1 \\
\hline Toplam & $\mathbf{1 5 7}$ \\
\hline
\end{tabular}

Tablo 2'de görüldüğü gibi öğretmenlerin “Ödev denildiğinde ne anl1yorsunuz? Ödev sizin için nasıl bir anlam ifade ediyor?" sorusuna ilişkin cevap kodlarında birinci sırada 28 frekans ile "pekiştirme ve tekrar" yer almaktadır. İkinci sırada 19 frekans ile "görev ve sorumluluk" yer alırken; üçüncü sırada 17 frekans ile "her türden çalışma ve etkinlik" cevabı yer almaktadır. Tablonun en sonunda "hedefe ulaşma yolu" ve "öğrenciyi olumlu yöne sevk etme aracı" cevaplarının ise birer frekans ile yer aldığı görülmektedir. 
Tablo 3. Öğretmenlere Yöneltilen "Ödevin öğrencilere ne tür katkılar să̆layacă̆ını düşünüyorsunuz?" Sorusuna Verdikleri Cevaplarn Frekans Tablosu

\begin{tabular}{|c|c|}
\hline Kodlar & $\mathbf{f}$ \\
\hline Bilgiyi pekiştirme & 23 \\
\hline Sorumluluk & 17 \\
\hline Öğrenilenleri tekrar etme & 15 \\
\hline Araştırma yapma & 12 \\
\hline Derse hazırlık & 11 \\
\hline Düşünme becerileri & 9 \\
\hline Kalıcı öğrenme & 8 \\
\hline Bilgiyi artırma & 8 \\
\hline Etkili öğrenme & 8 \\
\hline Başarıyı artırma & 7 \\
\hline Disiplin ve düzen & 7 \\
\hline Beceri ve yetenek & 7 \\
\hline Yaratıcilık & 6 \\
\hline Öğrenmeyi destekleme ve güçlendirme & 6 \\
\hline Özgüven & 5 \\
\hline Zaman yönetimi & 5 \\
\hline Karşılaştırma ve değerlendirme becerisi & 4 \\
\hline Bilgiyi keşfetme & 4 \\
\hline Otokontrol & 4 \\
\hline Düzenli ders çalışma alışkanlığı & 4 \\
\hline Öz değerlendirme & 3 \\
\hline Merak uyandırma & 3 \\
\hline Okuma alışkanlığ & 2 \\
\hline Özetleme ve raporlama becerisi & 2 \\
\hline Problem çözme becerisi & 2 \\
\hline Aile ile verimli zaman geçirme & 1 \\
\hline Araştırmacı kişilik geliştirme & 1 \\
\hline Başarma duygusu & 1 \\
\hline Etkili iletişim kurma becerisi & 1 \\
\hline Toplam & 186 \\
\hline
\end{tabular}

Tablo 3'te görüldüğü gibi öğretmenlerin “Ödevin öğrencilere ne tür katkılar sağlayacağını düşünüyorsunuz?" sorusuna ilişkin cevap kodlarında birinci sırada 23 frekans ile "bilgiyi pekiştirme" yanıtı yer almaktadır. İkinci sırada 17 frekans ile "sorumluluk" yer alırken; üçüncü sırada 15 frekans ile "öğrenilenleri tekrar etme" cevabı yer almaktadır. Tablonun en sonunda ise "aile ile verimli zaman geçirme", "araştırmacı kişilik geliştirme", "başarma duygusu" ve "etkili iletişim kurma becerisi" cevapları birer frekans ile yer almaktadir. 
Tablo 4. Öğretmenlere Yöneltilen “Öğrencilerinize ödev veriyor musunuz? Genelde ne tür ödevler veriyorsunuz?" Sorusuna Verdikleri Cevaplarn Frekans Tablosu

\begin{tabular}{lc}
\hline Kodlar & f \\
\hline Değişik türlerde & 26 \\
Araştırma ödevi & 22 \\
Etkinlik yapma & 19 \\
Soru çözme & 14 \\
Kitap okuma & 11 \\
Konu tekrarı & 9 \\
Yazı yazma & 7 \\
Belirli bir konu hakkında bilgi edinme & 5 \\
Canlandırma & 4 \\
Gözlem yapma & 3 \\
Inceleme & 3 \\
Bilgisayar çıktısını yazıya dökme & 2 \\
Deney yapma & 2 \\
Hikâye yazma & 2 \\
Konuşma & 2 \\
Öğrendiklerini çevreyle ilişkilendirme & 2 \\
Özet ödevi & 2 \\
Planlama & 1 \\
Resim yapma & 1 \\
Deftere soru yazma & 1 \\
Söyleşi & 1 \\
Güncel konuları yorumlama & 1 \\
Toplam & 1 \\
\hline
\end{tabular}

Tablo 4’te görüldüğü gibi öğretmenlerin “Öğrencilerinize ödev veriyor musunuz? Genelde ne tür ödevler veriyorsunuz?" sorusuna ilişkin cevap kodlarında birinci sırada 26 frekans ile "değişik türlerde" yanıtı yer almaktadır. İkinci sırada 22 frekans ile "araştırma ödevi" yer alırken; üçüncü sırada 19 frekans ile "etkinlik yapma" yanıtı yer almaktadır. Tablonun en sonunda "özet ödevi", "planlama", "resim yapma", "deftere soru yazma", "söyleşi" ve "güncel konuları yorumlama" cevaplarının da birer frekans ile yer aldığı görülmektedir.

Tablo 5'te öğretmenlerin "Size göre ideal bir ödev nasıl olmalıdır? İdeal bir ödevin özellikleri sizce nelerdir?" sorusuna ilişkin cevap kodlarında birinci sırada 12 frekans ile "kısa ve öz olmalı" yanıtı yer almaktadır. İkinci sırada 11 frekans ile "araştırma yapmaya yöneltmeli" yanıtı yer alırken; üçüncü sırada yine 11 frekans ile "pekiştirmeye ve tekrara yönelik olmalı" yanitı yer almaktadır. 
Tablo 5. Öğretmenlere Yöneltilen "Size göre ideal bir ödev nasıl olmalıdır? İdeal bir ödevin özellikleri sizce nelerdir?" Sorusuna Verdikleri Cevaplarn Frekans Tablosu

\begin{tabular}{|c|c|}
\hline Kodlar & $\mathbf{f}$ \\
\hline Kısa ve öz olmalı & 12 \\
\hline Araştırma yapmaya yöneltmeli & 11 \\
\hline Pekiştirmeye ve tekrara yönelik olmalı & 11 \\
\hline Öğrenci seviyesine uygun olmalı & 10 \\
\hline Açık ve anlaşılır olmalı & 9 \\
\hline Öğrenciyi sıkmamalı ve zorlamamalı & 8 \\
\hline Öğrenci kendi yapabilmeli & 8 \\
\hline Nitelikli olmalı & 7 \\
\hline İlgi çekici olmalı & 7 \\
\hline Günlük hayatla ilişkili olmalı & 6 \\
\hline Yaratıcılığı desteklemeli & 6 \\
\hline Ekonomik zorluk çıkarmamalı & 6 \\
\hline Somut görsellerle desteklenmeli & 5 \\
\hline Sürece aileyi de dâhil etmeli & 5 \\
\hline Merak uyandırmalı & 4 \\
\hline Öğrenci merkezli olmalı & 4 \\
\hline Basit olmalı & 3 \\
\hline Çok yazı yazdırmamalı & 3 \\
\hline Düşünmeye ve yorumlamaya yöneltmeli & 3 \\
\hline Proje şeklinde olmalı & 2 \\
\hline Açık uçlu olmalı & 2 \\
\hline Çıkarım yapmayı desteklemeli & 2 \\
\hline Kisa olmamalı & 2 \\
\hline Uygulanabilir ve kontrol edilebilir olmalı & 2 \\
\hline Amaca uygun olmalı & 1 \\
\hline Çoklu zekâ kuramına uygun olmalı & 1 \\
\hline Kapsam geçerliliği yüksek olmalı & 1 \\
\hline Kaynakları ulaşılabilir olmalı & 1 \\
\hline Öğrenciyi motive edici olmalı & 1 \\
\hline Toplam & 143 \\
\hline
\end{tabular}

Tablonun en sonunda "amaca uygun olmalı", "çoklu zekâ kuramına uygun olmalı", "kapsam geçerliliği yüksek olmalı", "kaynakları ulaşılabilir olmalı" ve "öğrenciyi motive edici olmalı" yanttlarının ise birer frekans ile yer aldığı görülmektedir.

\section{Araştırmanın İkinci Sorusuna İlişkin Bulgular}

Öğrencilerin yapmış oldukları resimlerin analizinden elde edilen bulgular Tablo 6' da verilmiştir. 
Tablo 6. Öğrenci Resimlerinde Yer Alan Ögelere Ait Frekans Tablosu

\begin{tabular}{|c|c|}
\hline Figürler - Nesneler & $\mathbf{f}$ \\
\hline Çocuk figürü & 257 \\
\hline Kitap / Defter & 202 \\
\hline Masa & 171 \\
\hline Sandalye & 133 \\
\hline Kalem / Silgi & 126 \\
\hline Dolap / Kitaplık & 67 \\
\hline Lamba / Avize & 67 \\
\hline Güneş & 57 \\
\hline Yatak & 52 \\
\hline Okul sırası & 50 \\
\hline Okul tahtası & 48 \\
\hline Bulut & 47 \\
\hline Ev binası & 44 \\
\hline Öğretmen figürü & 44 \\
\hline Kapı & 28 \\
\hline Çiçek & 26 \\
\hline Hayvan (Kelebek, Kuş, Kedi, Köpek v.b.) & 26 \\
\hline Okul binası & 25 \\
\hline Oyuncak & 24 \\
\hline Duvar saati & 21 \\
\hline Anne / Kadın figürü & 20 \\
\hline Ağaç & 19 \\
\hline Türk bayrağ & 18 \\
\hline Okul çantası & 16 \\
\hline Pencere & 15 \\
\hline Cetvel & 15 \\
\hline Halı & 13 \\
\hline Baba / Adam figürü & 10 \\
\hline Televizyon & 9 \\
\hline Bilgisayar (Masaüstü / Laptop) & 8 \\
\hline Araba / Taşıt & 7 \\
\hline Koltuk / Kanepe & 7 \\
\hline Meyve (Elma, Kiraz, Çilek, Portakal v.b.) & 6 \\
\hline Dağ & 5 \\
\hline Makas & 5 \\
\hline Duvar tablosu & 5 \\
\hline Çöp kovası & 4 \\
\hline Gökkuşağı & 2 \\
\hline Uçak & 2 \\
\hline Astronot & 1 \\
\hline Buzdolabı & 1 \\
\hline Dünya & 1 \\
\hline Toplam & 1707 \\
\hline
\end{tabular}

Tablo 6’ da görüldügüü üzere öğrencilere yöneltilen “Ödev denince aklınıza neler geliyor? Resmini çiziniz" yönlendirmesinden sonra çizilen resimler 
analiz edilmiş, resimlerde yer alan figürler de frekans analizine tabi tutulmuştur. Analiz sonunda resimlerde en çok yer alan figürün çocuk figürü olduğu görülmektedir. İkinci, üçüncü ve dördüncü sıralarda kitap/defter, masa ve sandalye figürlerinin yer aldığı görülmektedir. Tabloda beşinci, altıncı ve yedinci sıralarda yer alan kalem/silgi, dolap/kitaplık ve lamba/ avize gibi figürlerin yer aldığ 1 da görülebilir. Tablonun son sıralarında astronot, dünya, roket, yıldız, gezegen gibi figürler yer almaktadır.

\section{Araştırmanın Üçüncü Sorusuna İlişkin Bulgular}

Bu başlıkta velilerin ödevlere yükledikleri anlamların incelenmesi amacıyla velilerle yapılan yazılı görüşmelerin analizinden elde edilen bulgulara yer verilmiştir.

Tablo 7: Velilere Yöneltilen “Ödev denildiğinde ne anliyorsunuz? Ödev sizin için nasıl bir anlam ifade ediyor?" Sorusuna Verdikleri Cevaplarn Frekans Tablosu

\begin{tabular}{lc}
\hline Kodlar & f \\
\hline Tekrar ve pekiştirme çalışmaları & 165 \\
Görev & 55 \\
Sorumluluk & 51 \\
Derse ön hazırlık & 39 \\
Ders sonrası ev çalışması & 36 \\
Stres ve sıkıntı kaynağı & 23 \\
Bilgi eksikliklerini tamamlama aracı & 21 \\
Öğrenci-veli iletişimine katkı sağlama çalışması & 17 \\
Düzen ve disiplin & 16 \\
Öğrenme takibi & 12 \\
Kalıcı öğrenmenin sağlanması için bir araç & 9 \\
Veli-öğrenci-öğretmen işbirliği & 8 \\
Öğrenmeye destek & 7 \\
Zamanı dikkatli kullanma aracı & 6 \\
Bilginin derinleşmesini sağlayan bir araç & 5 \\
Öğrenmeyi hızlandırma çalışması & 5 \\
Okuma alışkanlığı kazandırma çalışması & 4 \\
Problem çözümleri & 4 \\
Anlaşılamayan konuyu belirleme yolu & 3 \\
Planlı ve programlı çalışma & 3 \\
Yazı yazma zorunluluğu & 491 \\
\hline Toplam & 2 \\
\hline
\end{tabular}


Tablo 7'de görüldügü gibi velilerin “Ödev denildiğinde ne anlıyorsunuz? Ödev sizin için nasıl bir anlam ifade ediyor?" sorusuna ilişkin cevap kodlarında birinci sırada 165 frekans ile "tekrar ve pekiştirme çalışmaları" yanıtı yer almaktadır. İkinci sırada 55 frekans ile "görev" tanımı yer alırken; üçüncü sırada ise 51 frekans ile "sorumluluk" yanıtı yer almaktadır. Tablonun en sonunda ise "okuma alışkanlığ 1 kazandırma çalışması", "problem çözümleri", "anlaşılamayan konuyu belirleme yolu”, "planlı ve programlı çalışma" ve "yazı yazma zorunluluğu" gibi yanıtların ise beşten az frekans ile yer aldığı görülmektedir.

Tablo 8. Velilere Yöneltilen “Ödevin çocuğunuza ne tür katkılar sağlayacağını düşünüyorsunuz ?" Sorusuna Verdikleri Cevaplarn Frekans Tablosu

\begin{tabular}{lc}
\hline Kodlar & f \\
\hline Öğrenilenlerin pekişmesi ve kalıcı olması & 157 \\
Görev ve sorumluluk bilinci & 75 \\
Disiplinli ve düzenli çalışma alışkanlığı & 36 \\
Akademik başarıyı artırma & 27 \\
Konuları daha iyi kavrama & 19 \\
Eksiklerini belirleme & 14 \\
Disiplin ve düzen & 11 \\
Teknoloji yerine kitap okumaya yönelme & 9 \\
Zamanı etkin kullanma becerisi & 8 \\
Araştırma becerisi & 8 \\
Sorgulama becerisi & 7 \\
Öğrenmenin takibi & 6 \\
Özgüven & 6 \\
Bilgiyi kullanma ve hayata uyarlama becerisi & 5 \\
Aile-çocuk iletişimine katkı & 4 \\
Yorumlama yeteneği & 4 \\
Hılı ve pratik düşünme becerisi & 3 \\
Rapor hazırlama ve sunma becerisi & 3 \\
Problem çözme becerisi & 2 \\
Bağımsı çalışma alışkanlığı & 2 \\
Merak duygusu uyandırma & 2 \\
Muhakeme yeteneği kazanma & 2 \\
Ayrıntılar üzerinde rahat düşünebilme becerisi & 2 \\
Derinlemesine bilgi kazanımı & $\mathbf{4 1 4}$ \\
Okul dışı tekrar bilinci &
\end{tabular}


Tabloda görüldüğü gibi velilerin “Ödevin çocuğunuza ne tür katkılar sağlayacağını düşünüyorsunuz ?" sorusuna ilişkin cevap kodlarında birinci sırada 157 frekans ile "öğrenilenlerin pekişmesi ve kalıcı olması" yanıtı yer almaktadır. İkinci sırada 75 frekans ile "görev ve sorumluluk bilinci" tanımı yer alırken; üçüncü sırada ise 36 frekans ile "disiplinli ve düzenli çalışma alışkanlığı" yanıtı yer almaktadır. Tablonun en sonunda ise "ayrıntılar üzerinde rahat düşünebilme becerisi", "derinlemesine bilgi kazanımı", "okul dışı tekrar bilinci" ve "otokontrol" cevapların birer frekans ile yer aldığı görülmektedir.

Tablo 9. Velilere Yöneltilen "Size göre ödev nasıl olmalıdır? İdeal bir ödevin özellikleri sizce nelerdir?" Sorusuna Verdikleri Cevaplarn Frekans Tablosu

\begin{tabular}{lc}
\hline Kodlar & F \\
\hline Konu tekrarı şeklinde olmalı & 93 \\
Az ve öz olmalı & 71 \\
Öğrenciyi sıkmamalı ve yormamalı & 58 \\
Eğlenceli ve ilgi çekici olmalı & 37 \\
Pekiştirici ve kalıcı olmalı & 31 \\
Eğitici ve öğretici olmalı & 24 \\
Seviyeye Uygun Olmalı & 22 \\
Zor Olmamalı & 16 \\
Kitap Okutulmalı & 11 \\
Test şeklinde ve sınavlara hazırlık niteliğinde olmalı & 11 \\
Beceri ve muhakeme gücünü geliştirici olmalı & 10 \\
Araştırmaya yönelik olmalı & 9 \\
Görsellerle desteklenmiş olmalı & 8 \\
Yaratıcılığı geliştirmeli & 8 \\
Sorumluluk duygusunu geliştirmeli & 7 \\
Yalnız başına yapabileceği tarzda olmalı & 5 \\
Açı ve anlaşılır olmalı & 5 \\
Bir sonraki güne veya konuya hazırlık niteliğinde olmalı & 4 \\
Ezbere yönelik olmamalı & 4 \\
Ceza yöntemiyle kontrol edilmeli & 436 \\
\hline Toplam & \\
\hline
\end{tabular}

Tablo 9'da görüldüğü gibi velilerin "Size göre ödev nasıl olmalıdır? İdeal bir ödevin özellikleri sizce nelerdir?" sorusuna ilişkin cevap kodlarında birinci sırada 93 frekans ile "konu tekrarı şeklinde olmalı" yanıtı yer almaktadır. İkinci sırada 71 frekans ile “az ve öz olmalı' yanıtı yer alırken; 
üçüncü sırada ise 58 frekans ile "öğrenciyi sıkmamalı ve yormamalı" yanitı yer almaktadır. Tablonun en sonunda "bir sonraki güne veya konuya hazırlık niteliğinde olmalı", "ezbere yönelik olmamalı" ve "ceza yöntemiyle kontrol edilmeli" gibi yanıtların beşten az frekans ile yer aldığı görülmektedir.

\section{Araştırmanın Dördüncü Sorusuna İlişkin Bulgular}

Öğretmenlerin ve velilerin ev ödevlerine yükledikleri anlamlar arasında benzer ve farklı yönlerin neler olduğunu belirlemek için öğretmen ve velilerin cevapları karşılaştırılmıştır. Benzer ve farklı yönler ödevin anlamı, ödevin öğrenciye sağlayacağı katkı ve ideal ödev süreçleri olmak üzere üç başlık altında tablolaştırılmıştır.

Tablo 10. Öğretmenlerin ve Velilerin Ödevin Anlamına İlişkin Görüşlerinde Benzer ve Farklı Yönler

\begin{tabular}{lll}
\hline Benzer Yönler & \multicolumn{2}{c}{ Farklı Yönler } \\
\cline { 2 - 3 } & Öğretmen & Veli \\
\hline Pekiştirme ve Tekrar & $\begin{array}{l}\text { Her Türden Çalışma ve } \\
\text { Etkinlik }\end{array}$ & Ders Sonrası Ev Çalışması \\
Görev ve Sorumluluk & Zorlama ve Eziyet Yöntemi & Stres ve Sıkıntı Kaynağı \\
Derse Ön Hazırlık & Gelişme Aracı & Öğrenme Takibi \\
Düzen ve Disiplin & Bilgiyi Keşfetme Yolu & Veli, Öğrenci ve Öğretmen \\
& Isşbirliği \\
Zamanı Etkili Kullanma & Hedefe Ulaşma Yolu & Yazı Yazma Zorunluluğu \\
\hline
\end{tabular}

Tablo 10' da görüldüğü gibi öğretmenler ve veliler ödevin; pekiştirme ve tekrarı ve derse ön hazırlığı sağlayacağı, zamanı etkili kullanma becerisini ve sorumluluk duygusunu kazandıracağ getireceği konusunda hemfikirlerdir. Öğretmenler, ödevi; bir gelişme arac1, hedefe ulaşma yolu, bilgiyi keşfetme yolu olarak görürken veliler; ev çalışması, stres ve sıkıntı kaynağı, öğrenmenin takibi, işbirliği ve yazı yazma zorunluluğu olarak algılamaktadırlar.

Tablo 11'de görüldüğü gibi öğretmenlerin ve velilerin ödevin öğrencilere sağlayacağ 1 katkıya ilişkin görüşlerinde benzer yönler pekiştirme ve kalıcılık, görev ve sorumluluk bilinci, akademik başarıyı artırma, zaman yönetimi gibi cevaplar olarak yer almaktadır. 
Tablo 11. Öğretmenlerin ve Velilerin Ödevin Öğrencilere Sağlayacağı Katkıya İlişkin Görüşlerinde Benzer ve Farklı Yönler

\begin{tabular}{|c|c|c|}
\hline \multirow[t]{2}{*}{ Benzer Yönler } & \multicolumn{2}{|c|}{ Farklı Yönler } \\
\hline & Öğretmen & Veli \\
\hline Pekiştirme ve Kalıcılık & $\begin{array}{l}\text { Öğgrenilenleri Tekrar } \\
\text { Etme }\end{array}$ & $\begin{array}{l}\text { Teknoloji Yerine Kitap Okumaya Yö- } \\
\text { neltme }\end{array}$ \\
\hline Görev ve Sorumluluk Bilinci & Derse Hazırlık & Eksiklerini Belirleme \\
\hline Akademik Başarıyı Artırma & Bilgiyi Artırma & $\begin{array}{l}\text { Bilgiyi Kullanma ve Hayata Uyar- } \\
\text { lama }\end{array}$ \\
\hline Zaman Yönetimi & Etkili Öğrenme & $\begin{array}{l}\text { Ayrıntılar Üzerine Rahat Düşünebil- } \\
\text { meBecerisi }\end{array}$ \\
\hline Problem Çözme Becerisi & $\begin{array}{l}\text { Etkili İletişim Kurma Be- } \\
\text { cerisi }\end{array}$ & Çocuk - Aile İletişimine Katkı \\
\hline Otokontrol & Bilgiyi Keşfetme & Yorumlama Yeteneği \\
\hline Düzenli Çalışma Alışkanlığı & $\begin{array}{l}\text { Öğrenmeyi Destekleme } \\
\text { ve Güçlendirme }\end{array}$ & Öğrenmenin Takibi \\
\hline $\begin{array}{l}\text { Rapor Hazırlama Becerisi } \\
\text { Araştırma Becerisi } \\
\text { Özgüven } \\
\text { Merak Duygusu Uyandırma }\end{array}$ & Başarma Duygusu & Konuları Daha İyi Kavrama \\
\hline
\end{tabular}

Farklı yönler incelendiğinde ise öğretmenlerin ödevin öğrencilere sağlayacağı katkıya ilişkin öğrenilenleri tekrar etme, derse hazırlık, bilgiyi artırma, etkili öğrenme gibi ifadelerine karşılık velilerin teknoloji yerine kitap okumaya yöneltme, eksiklerini belirleme, bilgiyi kullanma ve hayata uyarlama olarak ifade ettikleri görülmektedir.

Tablo 12'de görüldüğü gibi öğretmenlerin ve velilerin ideal ödeve ilişkin görüşlerinde benzer yönler; az ve öz olmalı, öğrenciyi zorlamamalı ve sıkmamalı, araştırmaya yöneltmeli, pekiştirme ve tekrara yönelik olmalı, öğrenci seviyesine uygun olmalı, açık ve anlaşılır olmalı gibi cevaplar olarak yer almaktadır. Farklı yönler incelendiğinde ise öğretmenlerin ideal ödeve ilişkin; günlük hayatla ilişkili olmalı, nitelikli olmalı, ekonomik zorluk çıkarmamalı, sürece aileyi de dâhil etmeli, merak uyandırmalı, çok yazı yazdırmamalı gibi ifadelerine karşılık velilerin; kitap okutulmalı, test şeklinde olmalı, sinavlara hazırlık niteliğinde olmalı, muhakeme gücü ve sorumluluk duygusu geliştirmeli gibi cevaplarla ideal ödeve ilişkin görüşlerini ifade ettikleri görülmektedir. 
Tablo 12. Öğretmenlerin ve Velilerin İdeal Ödeve İlişkin Görüşlerinde Benzer ve Farklı Yönler

\begin{tabular}{lll}
\hline \multirow{2}{*}{ Benzer Yönler } & \multicolumn{1}{c}{ Farklı Yönler } \\
\cline { 2 - 3 } & Öğretmen & Veli \\
\hline Az ve Öz Olmalı & $\begin{array}{l}\text { Günlük Hayatla İliş̧ili } \\
\text { Olmalı }\end{array}$ & Kitap Okutulmalı \\
\hline Öğrenciyi Sıkmamalı ve & Nitelikli Olmalı & $\begin{array}{l}\text { Test Şeklinde Ol- } \\
\text { malı }\end{array}$ \\
\hline Araştırmaya Yöneltmeli & Ekonomik Zorluk & $\begin{array}{l}\text { Sınavlara Hazırlık } \\
\text { Niteliğinde Olmalı }\end{array}$ \\
\hline $\begin{array}{l}\text { Pekiştirme ve Tekrar } \\
\text { Yönelik Olmalı }\end{array}$ & Sürece Aileyi Dahil Etmeli & $\begin{array}{l}\text { Muhakeme Gücünü } \\
\text { Geliştirmeli }\end{array}$ \\
\hline $\begin{array}{l}\text { Öğrenci Seviyesine Uygun } \\
\text { Olmalı }\end{array}$ & Merak Uyandırmalı & $\begin{array}{l}\text { Sorumluluk Duy- } \\
\text { gusu Geliştirmeli }\end{array}$ \\
\hline Açık ve Anlaşılır Olmalı & Çok Yazı Yazdırmamalı & $\begin{array}{l}\text { Ezbere Yönelik Ol- } \\
\text { mamalı }\end{array}$ \\
\hline Zor Olmamalı & Proje Şeklinde Olmalı & Ceza Yöntemiyle \\
& & Kontrol Edilmeli \\
\hline Görsellerle Desteklenmeli & Açık Uçlu Olmalı & \\
\hline Eğlenceli ve İlgi Çekici & Çoklu Zekâ Kuramına & \\
Olmalı & Uygun Olmalı & \\
\hline $\begin{array}{l}\text { Öğrencinin Kendisinin Yapabi- } \\
\text { leceği Nitelikte Olmalı }\end{array}$ & Kapsam Geçerliliğgi & \\
\hline Yaratıcılığı Desteklemeli & Yüksek Olmalı & \\
\hline & Öğrenciyi Motive Edici & \\
\hline & Olmalı & \\
\hline
\end{tabular}

\section{Tartışma}

Öğretmenler, ödeve; pekiştirme ve tekrar, görev ve sorumluluk, çalışma ve etkinlik, zorlama ve eziyet yöntemi, araştırma, derse ön hazırlık gibi anlamlar yüklemektedirler. Bu anlamların ödevin eğitimde varoluş nedenine uygun olduğu söylenebilir. Ancak “Ödev zorlama ve eziyet yöntemidir." düşüncesi dikkat çekicidir. Bu, bazı öğretmenlerce ödevin bir işi yapmaya zorlama ve eziyet olarak algılandığını düşündürmektedir. Bu durumda bu düşünceye sahip öğretmenlerin ödev vermedikleri ya da verseler bile bir faydası olmadığına inandıkları şeklinde yorumlanabilir. Öğretmenler, ödevin; tekrar, sorumluluk, araştırma, derse hazırlık, düşünme becerilerinin gelişimi gibi katkılar sağlayacağını düşünmektedirler. Öğ- 
retmenlerin ödevin katkılarına ilişkin görüşlerinin de ödevin eğitimde varoluş nedenine uygun olduğu söylenebilir. Öğretmenler genellikle araştırma, etkinlik yapma, soru çözme, okuma, tekrar etme, yazma ödevleri vermektedirler. Buradan daha çok alışılagelmiş ödevlerin verildiği anlaşılmaktadır. Özellikle Türkiye' de 2006 yılından beri uygulamada olan öğretim programlarının özellikleri dikkate alındığında deney yapma, gözlem yapma, röportaj yapma vb. ödevlerin listede yer alması gerekirdi. Bu durumda, öğretim programının ya da dersin amacına uygun ödev verilmediği, alışkanlıkların devam ettiği söylenebilir. Öğretmenlere göre ideal bir ödev kısa ve öz; tekrara yönelik; öğrenci seviyesine uygun; açık anlaşılır, öğrencinin kendisinin yapabileceği şekilde olmalıdır. Ayrıca araştırma yapmaya yöneltmelidir ve öğrenciyi sıkmamalıdır. Öğretmenlerin ideal ödevin nasıl olması gerektiğine yönelik görüşlerinin ödevin amaçları ile uyumlu olduğu söylenebilir.

Öğrencilerin yapmış oldukları resimlerde en çok yer alan figürün çocuk figürü olduğu görülmektedir. Resimlerin bir kısmında öğrenciler kendilerini ödev yaparken resmetmişler, bir kısmında ise kendilerinin ve arkadaşlarının bulunduğu bir ortamı resmetmeyi tercih etmişlerdir. En çok dikkat çeken bölüm ise ikinci, üçüncü ve dördüncü sıralarda kitap/defter, masa ve sandalye figürlerinin olmasıdır. Buna göre öğrencinin ödev denilince aklına en çok gelen objeler kitap, defter, masa ve sandalye olmaktadır. Buradan hareketle öğrencilerin ödeve genellikle kapalı mekânda, masa başında oturularak yapılan, kitap veya defterlerin kullanıldığı çalışmalar olarak düşündüğü söylenebilir. Yine iç mekân objesi olan çalışma masasının ve sandalyenin sıkça figür olarak resimlerde karşımıza çıkması öğrencilerin genellikle ödevlerini kapalı mekânlarda yaptıkları hakkında ipucu vermektedir. Beşinci, altıncı ve yedinci sıralarda yer alan kalem/silgi, dolap/ kitaplık ve lamba/avize gibi figürlerin de genellikle iç mekân objesi olması bu görüşü daha da kuvvetlendirmektedir. Güneş, bulut, ağaç, çiçek gibi figürlerin de resimlerde yer alması, ödevin öğrencide doğa, açık hava çağrısımını da yaptığını göstermektedir. Fakat bu figürlerin lamba, masa, sandalye gibi kapalı mekân nesnelerine göre sayı bakımından daha az olarak yer alması ödevlerin çoğunlukla kapalı mekânlarda yapıldığı hakkında ipucu vermektedir. Tablonun son sıralarında yer alan astronot, dünya, roket, yıldız, gezegen gibi figürler dikkate 
alındığında ödevin öğrencilerin hayal dünyasına ait objeleri çağrıştırdığ1 söylenebilir. Yatak figürünün ilk on sırada yer alması dikkat çekicidir. Bu, ödevin öğrenciler için sıkıcı ve yorucu bir iş olarak algılandığı şeklinde yorumlanabilir. Öğrenci resimlerinden elde edilen bulgular da alışılagelmiş ödevlerin verildiği yorumunu desteklemektedir.

Veliler, ödeve; tekrar, görev, sorumluluk, derse hazırlık, stres ve sıkıntı kaynağı, disiplin, öğrenmenin takibi gibi anlamlar yüklemektedirler. Velilere göre ödev; öğrenilenleri pekiştirir, görev ve sorumluluk bilinci kazandırır, disiplin sağlar, akademik başarıyı arttırır ve öğrenme eksikliklerini belirler. Velilere göre ideal bir ödev konu tekrarı şeklinde, az ve öz, eğlenceli ve ilgi çekici, pekiştirici ve kalıcı, eğitici ve öğretici, seviyeye uygun, test şeklinde ve sınavlara hazırlık niteliğinde, muhakeme gücünü geliştirici nitelikte olmalıdır. Ayrıca öğrenciyi sıkmamalıdır ve yormamalıdır, zor olmamalıdır ve kitap okutmalıdır. Velilerin ödevin anlamı, sağlayacağı katkılar ve ideal bir ödevin nasıl olması gerektiğine ilişkin görüşlerinin ödevin eğitimde varoluş nedenine uygun olduğu söylenebilir. Ancak velilerin ideal ödeve ilişkin görüşlerindeki çelişki dikkat çekmektedir. Veliler hem zorlamamalı, sıkmamalı, muhakeme gücünü geliştirmeli, kitap okutmalı şeklinde görüş bildirirlerken hem de test şeklinde olmalı ve sinavlara hazırlamalı demektedirler. Bu durum sinavın veliler üzerinde bir baskı oluşturduğu şeklinde yorumlanabilir.

\section{Sonuç ve Öneriler}

Öğretmenlerin ve velilerin ödeve ilişkin görüşlerinin genel olarak benzeştiği söylenebilir. Öğretmen ve velilerin farklı görüşleri de vardır. Örneğin ödevin sağlayacağı katkılara yönelik görüşlerde veliler farklı olarak "kitap okumaya yöneltmeli" şeklinde görüş belirtmişlerdir. Bunun gibi farklılıklar vardır. Bu farklılıkların ödev konusunda yaşanan problemlerin nedeni olamayacağı söylenebilir. Bu araştırmanın argümanı şuydu: Ödev konusunda sıkıntılar yaşanmaktadır, ödev bir problemdir. Yaşanan problemlerin nedeni paydaşların ödevin anlamına, ödevin katkılarına ve ideal bir ödeve yönelik görüşlerinin farklı olması olabilirdi. Bu nedenle bu çalışmada her bir paydaşın görüşleri belirlenecek, benzer ve farklı yönler ortaya çıkarılacak, benzer yönlere odaklanılarak önerilerde bulunulacaktı. 
Bulgular incelendiğinde öğretmenlerin ve velilerin görüşlerinin genel olarak benzeştiği görülmektedir. Farklı yönlerin yaşanılan problemlerin kaynağı olabilecek türden olmadığı söylenebilir. Yaşanılan problemlerin nedeninin ne olabileceği yeni araştırmalarda irdelenmelidir. Öğretmenlerin ve velilerin ödevin amacına, katkılarına ve nasıl olmasına gerektiğine yönelik görüşleri büyük ölçüde benzeştiğine göre yaşanan problemlerin nedenin ödevin türü ve miktarından kaynaklandığı söylenebilir. Ancak, ödev verilirken buradaki benzer yönlere odaklanılmasının ödevin etkililiğini arttıracağı ve paydaşlar arasında yaşanacak sıkıntıları en aza indirmede katkılar sağlayacağı söylenebilir. 
EXTENDED ABSTRACT

\title{
Homework: Opinions of Teachers, Students and Parents
}

\author{
* \\ Mustafa Ok- Muhittin Çalışkan \\ Pema College-Necmettin Erbakan University
}

The aim of this study is to determine the opinions of teachers, students and parents about homework at primary school level. For this purpose, this study addresses four questions: 1 . What is the meaning of homework attributed by teachers? 2. What is the meaning of homework attributed by students? 3. What is the meaning of homework attributed by parents? 4 . What are the similar and different aspects between the meaning of homework attributed by teachers and parents?

This study, which aims to investigate the meaning of homework attributed by teachers, students and parents, was carried out by using phenomenology pattern, which is one of the qualitative research patterns. The participants of this study were 335 students, 222 parents and 37 teachers working in two primary schools, one private school and one state school. The data were collected through two separate semi-structured interview forms for teachers and parents and the pictures drawn by students. Content analysis was used to analyse the data obtained from the interview forms, and visual analysis techniques were used in the analysis of the data obtained from the students' pictures.

The findings obtained in this study are summarized in four paragraphs. The first paragraph shows the opinions of the teachers, the second paragraph displays the opinions of the students, the third paragraph indicates the opinions of the parents and the fourth paragraph summarizes the similar and different aspects between the meaning of homework attributed by teachers and parents.

Teachers answered the question "What does homework mean to you?" as repetition, task and responsibility. Teachers claimed that the homework would contribute to students' reinforcement of knowledge, responsibility and repetition of learning. Teachers stated that they usually assigned 
homework as research and activities. Teachers defined short and concise homework which leads students to do research as ideal homework.

The students were asked to draw pictures to respond to the statement "What do you think of the assignment? Draw your picture." The pictures drawn were analysed and the figures in the pictures were subjected to frequency analysis. At the end of the analysis, it was found that the figure which appeared most in the pictures is the child figure. The following figures were book / notebook, desk and chair, pencil / eraser, cabinet / bookcase and lamp / chandelier, respectively. The least frequent figures were astronaut, world, rocket, star and planet.

Parents answered the question "What does homework mean to you?" as repetition and reinforcement studies, task and responsibility. Parents stated that they believed homework would contribute to students' reinforcement and retention of knowledge, help students gain awareness of task and responsibility along with the disciplined and regular working habits. According to parents, the ideal homework should be short and concise, repeat the subjects learned and should not be boring.

Both teachers and parents attributed meanings such as reinforcement / repetition and task / responsibility to homework. Apart from this, parents regarded homework as a source of boredom and stress. Both teachers and parents stated that homework would contribute to reinforcement and retention, increasing awareness of task and responsibility, increasing academic achievement and time management. Distinctively, teachers declared that homework would contribute to repetition, preparation for lessons, increasing knowledge, effective learning, and parents stated that homework would direct student to read books instead of technology, help students determine their weaknesses, use information and adapt it to life. According to both teachers and parents, the ideal homework should be short and concise. It should not be too difficult and boring, and should lead the student to do research and be aimed at repetition and reinforcement. In addition, it should be clear, comprehensible and suitable for the students' level. Furthermore, according to teachers, the ideal homework should be qualified and related to daily life, should not lead to economic difficulty, should include the family in the process, arouse curiosity and should not require too much text writing. Unlike teachers, parents' opin- 
ions on the ideal homework can be listed as follows: It should lead students to read books, be in the form of tests, prepare students for the exams, improve their sense of reasoning and responsibility.

As a result, it could be argued that teachers and parents have mostly similar opinions about the meaning and contribution of homework and how an ideal homework should be. It could be inferred from the students' pictures that students are generally assigned reading-writing tasks as homework. It is believed that the problems experienced when homework is assigned can be minimized considering the similar opinions obtained as a result of this study.

\section{Kaynakça / References}

Bilgin, N. (2014). Sosyal bilimlerde içerik analizi teknikler ve örnek çalışmalar. (3. Bask1). Ankara: Siyasal Kitabevi.

Büyüktokatlı, N. (2009). Illköğretimde ev ödevi uygulamalarına ilişkin öğretmen görüşlerinin incelenmesi. Yayımlanmamış yüksek lisans tezi, Selçuk Üniversitesi, Konya.

Deveci, İ. (2011). Fen ve teknoloji dersi kapsamında ilköğretim yedinci ve sekizinci smıflarda verilen ödevler hakkında öğrenci, öğretmen ve veli görüşleri. Yayımlanmamış yüksek lisans tezi, Sakarya Üniversitesi, Sakarya.

Gedik, M. ve Orhan, S. (2013). İlköğretim 6. ve 7. sınıf öğrencilerinin Türkçe dersi ödevleri hakkındaki görüşleri. Karadeniz Araştırmaları Dergisi, 38, 135-148.

Gedik, N., Altıntaş, E. ve Kaya, H. (2011). Fen ve teknoloji dersinde verilen ev ödevleri hakkındaki öğrenci görüşleri. Journal Of European Education, 1(1), 6-13.

Gür, H. (2002). Ev ödevi yapma stillerinin akademik başarıya etkisi [Öz]. 5.Ulusal Fen Bilimleri ve Matematik Eğitimi Kongresi'nde sunulmuş sözlü bildiri, Ortadoğu Teknik Üniversitesi, Ankara. 31.10.2017 tarihinde http://old.fedu.metu.edu.tr/ufbmek-5/ozetler/d074.pdf adresinden erişildi.

Gürlevik, G. (2006). Ortaöğretim matematik derslerinde ev ödevlerine yönelik öğretmen ve öğrenci görüşleri: Ankara ili Çankaya ilçesi örneği. Yayımlanmamış yüksek lisans tezi, Gazi Üniversitesi, Ankara. 
Hizmetçi, S. (2007). Illköğretim 5. sını öğrencilerinin ödev stilleri ile akademik başarıları arasındaki ilişkinin incelenmesi. Yayımlanmamış yüksek lisans tezi, Çukurova Üniversitesi, Adana.

Kapıkıran, Ş. ve Kıran, H. (1999). Ev ödevinin öğrencinin akademik başarısına etkisi, Pamukkale Üniversitesi Eğitim Fakültesi Dergisi, 5(5), 1226.

Kütükte, Z. (2010). Illköğretim öğretmenlerinin performans ve proje ödevlerine ilişkin algı görüş ve uygulama durumları. Yayımlanmamış yüksek lisans tezi, Gaziosmanpaşa Üniversitesi, Tokat.

Oğuz, M. A. (2010). Ortaöğretim coğrafya derslerinde ev ödevlerine yönelik öğretmen görüşleri:Yozgat ili örneği. Yayımlanmamış yüksek lisans tezi, Gazi Üniversitesi, Ankara.

Öcal, S. (2009). İlköğretim 4. ve 5. simı öğrencilerinin ev ödevlerine yönelik tutumlarının oluşmasında ailelerin ve öğretmenlerin rolü. Yayımlanmamış yüksek lisans tezi, Mustafa Kemal Üniversitesi, Hatay.

Özer, B. ve Öcal, S. (2013). Sınıf öğretmenlerinin ev ödevlerine yönelik uygulamalarının ve görüşlerinin değerlendirilmesi. Uluslararası Türkçe Edebiyat Kültür Eğitim Dergisi, 2(1), 133-149.

Sönmez, V. ve Alacapınar, F. (2014). Örneklendirilmiş bilimsel araştırma yöntemleri. (3. bask1). Ankara: Anı Yayıncilık.

Şen, H. Ş. ve Gülcan, M. G. (2012). İlköğretim 4. ve 5. sınıflarda verilen ev ödevleri konusunda veli görüşleri. Gazi Üniversitesi Endüstriyel Sanatlar Eğitim Fakültesi Dergisi, 29, 29-41.

Tavşancil, E. ve Aslan, E. (2001). İçerik analizi ve uygulama örnekleri. İstanbul: Epsilon Yayıncilık.

Turanlı, A. S. (2007). Gerçek bir ikilem: Ödev vermek ya da vermemek? Sosyal Bilimler Araştırmaları Dergisi, 1, 136-154.

Turanlı, A. S. (2009a). Öğrencilerin ve anne - babaların ödeve ilişkin alg1ları. Eğitim ve Bilim Dergisi, 34(153), 61-73.

Turanlı, A. S. (2009b). Öğretmenlerin ödeve ilişkin görüşleri: ortamsal etmenlere dair nitel bir çalışma. Çukurova Üniversitesi Eğitim Fakültesi Dergisi, 37(3), 129-143.

Türkoğlu, A., İflazoğlu, A. ve Karakuş, M. (2014). Eğitim sürecinde ödev. İstanbul: Anı Yayıncilı. 
Yeşilyurt, S. (2006). Lise öğrencilerinin biyoloji derslerinde verilen ev ödevlerine karşı tutumları üzerine bir çalışma. Erzincan Ĕ̆itim Fakültesi Dergisi, 8(1), 37-53.

Yolcu, S. (2007). Internet ortaminda hizmet veren ödev sitelerinin eğitim-öğretim açısından değerlendirilmesi. Yayımlanmamış yüksek lisans tezi, Dokuz Eylül Üniversitesi, İzmir.

\section{Kaynakça Bilgisi / Citation Information}

Ok, M. ve Çalışkan, M. (2019). Ev ödevleri: Öğretmen, öğrenci ve veli görüşleri. OPUS-Uluslararası Toplum Araştırmaları Dergisi, 11(18), 594-621. DOI: 10.26466/opus.544599 